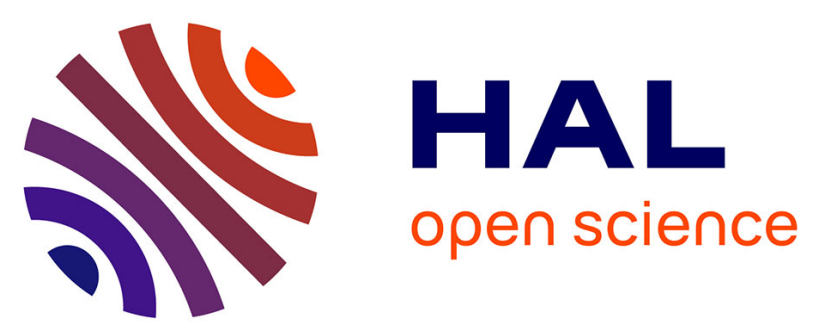

\title{
Sizing Optimization of a Charging Station Based on the Multi-scale Current Profile and Particle Swarm Optimization: Application to Power-assisted Bikes
}

Willy Magloire Nkounga, Mouhamadou Falilou Ndiaye, Francoise Grandvaux, Mamady Conde, Laurent Tabourot, Mamadou Lamine Ndiaye

\section{To cite this version:}

Willy Magloire Nkounga, Mouhamadou Falilou Ndiaye, Francoise Grandvaux, Mamady Conde, Laurent Tabourot, et al.. Sizing Optimization of a Charging Station Based on the Multi-scale Current Profile and Particle Swarm Optimization: Application to Power-assisted Bikes. 2021 Sixteenth International Conference on Ecological Vehicles and Renewable Energies (EVER), May 2021, Monte-Carlo, Monaco. pp.1-12, 10.1109/EVER52347.2021.9456626 . hal-03457476

\section{HAL Id: hal-03457476 \\ https://hal.univ-smb.fr/hal-03457476}

Submitted on 14 Dec 2021

HAL is a multi-disciplinary open access archive for the deposit and dissemination of scientific research documents, whether they are published or not. The documents may come from teaching and research institutions in France or abroad, or from public or private research centers.
L'archive ouverte pluridisciplinaire HAL, est destinée au dépôt et à la diffusion de documents scientifiques de niveau recherche, publiés ou non, émanant des établissements d'enseignement et de recherche français ou étrangers, des laboratoires publics ou privés. 


\section{Sizing optimization of a charging station based on the multi-scale current profile and particle swarm optimization: application to power-assisted bikes}

\author{
Willy Magloire Nkounga, \\ Univ. Savoie Mont Blanc, \\ SYMME, F-74000 Annecy, France \\ Laboratoire Eau-Energie- \\ Environnement-Procédés Industriels (LE3PI) \\ École Supérieure Polytechnique (ESP) \\ Université Cheikh Anta Diop (UCAD) \\ Email: willy-magloire.nkounga@univ-smb.fr, \\ welly-magloire.nkounga@ucad.edu.sn
}

\author{
Mouhamadou Falilou Ndiaye \\ LE3PI-ESP-UCAD \\ Email: mouhamadouf.ndiaye@ucad.edu.sn
}

\author{
Françoise Grandvaux \\ Univ. Savoie Mont Blanc, \\ SYMME, F-74000 Annecy, France \\ Email: francoise.grandvaux@univ-smb.fr
}

\author{
Mamady Condé \\ Laboratoire des Machines Electriques, \\ Université Gamal Abdel Nasser, Conakry \\ Email: madyconde76@gmail.com
}

Laurent Tabourot

Univ. Savoie Mont Blanc, SYMME, F-74000 Annecy, France

Email: laurent.tabourot@univ-smb.fr
Mamadou Lamine Ndiaye

LE3PI-ESP-UCAD

Email: mamadoulamine.ndiaye@ucad.edu.sn

\begin{abstract}
The development of power-assisted bikes (ebike) is of growing interest because of their economic and environmental advantages. The present work deals with the sizing optimization of a charging station for ebike based on particle swarm optimization. It is based on the consumption profile of ebike batteries, solar and wind power, installation, replacement and maintenance costs of components. In a first step, the consumption profile of the ebike batteries is determined using the second order non-linear electrothermal model. Then, the solar and wind data over one year are used to determine the availability of energy at the implementation site of the charging station. Finally, the cost is defined as an objective function, taking into account the constraints on the number of solar photovoltaic panels, the number of wind turbines, the number of storage batteries and the annual charging demand. The context of a charging station to be implemented in the Polytech Annecy campus in France is studied. The results show that the particle swarm optimization allows a cost reduction of around 56.04\% compared to a sizing without optimization.
\end{abstract}

Keywords—sizing optimization, charging station, particle swarm optimization, costs, ebike.

\section{INTRODUCTION}

The use of power-assisted bikes (ebike) is experiencing growing interest, due to their environmental benefits, easy mobility, low energy cost and reduced traffic flow [1]. This growth has created new challenges for investors: the charging time of ebike batteries, the scarcity of charging stations, the total coverage of charging demand. This work is focused on the last category.

To cover the charging demand, several works have proposed the use of a multi-source system, integrating solar, wind, storage battery, and/or local grid [2]-[4]. Given the intermittent nature of renewable energy sources, the main challenge of a multi-source system is to optimize the size of the energy sources to meet the charging demand, in order to minimize the total cost of the system [2]. Cost minimization in sizing a multi-source system depends on several factors: the technical constraints of the system, the charging demand profile, the energy resource availability and the objective 
function solving method.

Several cost functions are defined in the literature: energy cost (COE) [5], total net system cost (TNPC or NPC) [6], levelized cost of energy (LCOE) [4], annualized cost of the system (ACS) [2]. Among these cost functions, the cost of energy (COE) and total net cost (TNPC) are the most effective indicators of profitability in the economic analysis [7]. In this work the minimization of total net cost is used as an objective function. It takes into account the actualized costs of investment, replacement and maintenance costs of components.

The most used constraints in the literature to optimize the sizing of a multi-source system are: the charge/discharge limit of storage batteries, the balance between the energy produced from the sources (solar, wind) and the charging demand [8], the maximum and minimum number of sources, the state of health and charge of ebike batteries [9]. In this work, the number of solar panels (PV), wind turbine, the balance between $\mathrm{PV} /$ Wind energy and charging demand, as well as the state of health of ebike batteries are considered.

The batteries' state of health optimization depend on the charging protocol applied to its cells [10]; the protocols proposed in the literature are [11]: constant current constant voltage $(\mathrm{Cccv})$, multi-scale constant current (Mscc), Boost charging (Bc). Unlike the standard $\mathrm{Cccv}$ charging protocol, the Mscc, in addition to being adapted for industrial applications, has the particularity of reducing the implementation cost, which contributes to minimizing the sizing costs of the charging station. In recent years, Mscc has become increasingly popular for the battery charging protocol, as it helps to reduce charging costs and optimize the battery's state of health [10] [12]. The charging profile proposed in this work is based on the Mscc protocol.

The charging profile of ebike batteries is defined according to several variables: the maximum energy capacity they can consume, the difference between their initial and final states of charge. These states of charge can be determined from several models [10]: the first-order equivalent circuit, second-order electro-thermal circuit. The second order non-linear electro-thermal circuit is used in this work to model the charging profile of ebike batteries. It has the advantage of describing the real behavior of the battery cells, because the electrical parameters of such a model are validated by experimental tests.
The knowledge of the ebike charging profile, the charging protocol and the available energy allows an optimal sizing, choosing the right size of sources according to the charging demand and offering the lowest possible cost. Several sizing techniques are proposed in the literature [13] [14]: harmonic search algorithm, artificial bee colony algorithm, genetic algorithm (GA), Particle Swarm Optimization (PSO), dynamic programming, quadratic programming and convex optimization. Among these different techniques, PSO has the particularity to be adapted for a better sizing optimization of the components, because it offers a better alternative of source management with a significant cost reduction. The work [7] indicates that: PSO is very suitable for sizing, as it has the ability to handle non-linear problems and to avoid the local minimum solution. In this work, the PSO is used for sizing the ebike charging station.

The sizing of a $\mathrm{PV} /$ wind/diesel hybrid system is presented in the work [3]; the linear algorithm is used. The objective function used is the cost function integrating investment, maintenance and operating costs. The results show that the PSO allows to obtain an optimal sizing. In the work [15], a technical-economic analysis of a wind energy system is performed. The goal is to minimize the cost of energy in homes; Homer software is used. The results led to a cost reduction of $0.363 \$ / \mathrm{kWh}$. The sizing of an isolated PV/Diesel hybrid system based on the energy consumption profile is proposed in the work [5]. The cost of energy (COE) is used as an objective function with the Homer software considering only the replacement costs of components (batteries and converters). The results allowed to find a better system architecture with a fraction of $48.55 \%$ of renewable energy, an electricity cost of $250 \$ / \mathrm{MWh}$, and a greenhouse gas reduction of $69.6 \%$. PSO is used in [9] to size a PV/wind/grid hybrid system; the objective functions used are the energy cost and power loss minimization. The load profile used is that of the consumers' electricity demand. In the work [8], the economic analysis of a $\mathrm{PV} /$ wind/fuel-cell/grid hybrid system is proposed; the loads considered are domestic. The cost functions used are: the cost of purchasing electricity and the profit of selling the energy to the grid; the meta heuristic method and the harmonics search are combined; the results showed electricity cost of 0.0628 $\$ \mathrm{kWh}$ below $0.1 \$ \mathrm{kWh}$ of the conventional cost.

The PSO is used in the work [16] for energy management in hybrid electric vehicles by considering the vehicles' state of charge as a constraint: an consumption optimization of $59.55 \%$ is obtained 
compared to the consumption without optimization. In [17], the dynamic approximation method is used for demand and energy management of a charging station with cost minimization as an objective function. The results have led to a cost reduction of $50 \%$ compared to the conventional charging. In the work [2], PSO is used to size a PV/wind hybrid system. Electric vehicle batteries are integrated into domestic loads, and modeled by the Monte Carlo method. The objective functions are Life Cycle Cost (LCC) and Loss of power supply probability(Lpsp). The results show that, the inclusion of electric vehicles in loads increases the reliability of the system.

Although several optimization techniques for multisource systems are proposed in order to minimize costs, none of these works have addressed the problem of sizing a charging station using the PSO. Therefore, a new technique for sizing a charging station using PSO is proposed in this work, with the aim of minimizing the total cost of the system and satisfying the charging demand by using solar panel and wind turbines.

The novelty of this work is :

- $\quad$ sizing optimization of power-assisted bike charging station integrating PV/wind hybrid systems with the PSO.

- the application of the multi-scale constant current charging protocol to establish the ebike required consumption profile for the charging station.

In the rest of the document, section 2 deals with the presentation and description of the charging station and its components; section 3 describes the mathematical modeling of the photovoltaic, wind, storage battery system and the charging profile. In Section 5, the sizing results are presented and discussed. Finally, the conclusion and perspectives are presented in section 6 .

\section{PRESENTATION, DESCRIPTION AND MODELING} OF PV PANELS, WIND TURBINE, STORAGE BATTERIES AND POWER-ASSISTED BIKES.

The overall system configuration is shown in Figure 1 : The system consists of photovoltaic solar panel, wind turbine and storage batteries on the one hand; then direct current controllers, inverter, charging spots to which the ebike can be connected for simultaneous charging on the other hand. The storage batteries are chosen so that $\mathrm{PV} /$ wind energy is stored in the absence of the ebike and discharged when the total energy from PV/wind

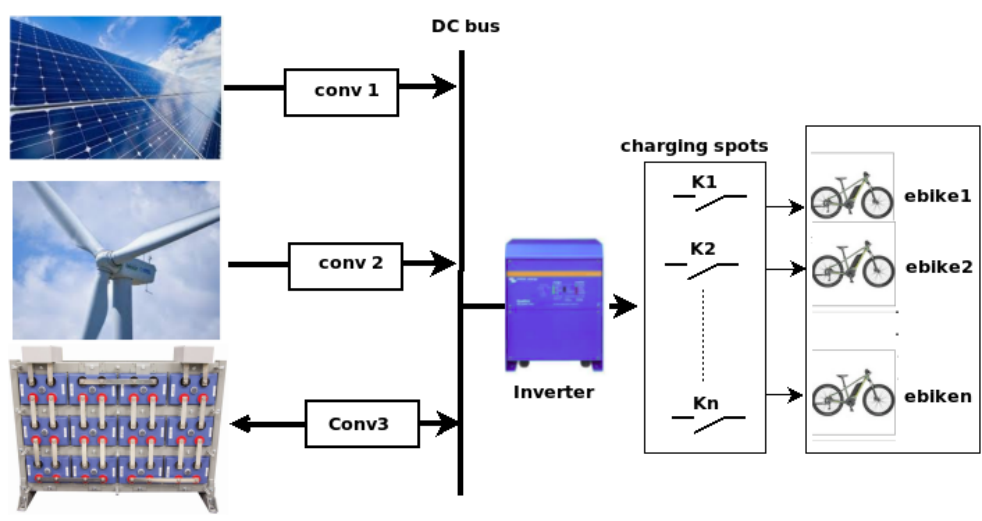

Figure 1. charging station

sources cannot cover the entire charging demand. The storage battery charging and discharging is controlled by bidirectional buck-boost controller (conv 3). PV and Wind energy output are controlled using boost converters (conv1 and conv2 respectively). These controllers make it possible to adapt the $\mathrm{PV} /$ wind/storage battery output voltages to the DC-bus voltage. The DC/AC inverter makes it possible to adapt the DC bus voltage to the alternating input voltage $(\mathrm{AC})$ of the ebike battery charger. switches are used for energy dispatching to the ebikes. The aim of this work is to find the best configuration to be able to exploit the available energy resource on the one hand, and then to satisfy the charging demand while respecting the constraints on the system on the other hand. The system constraints are: the number of photovoltaic solar panels and wind turbines, the number of storage batteries, the balance between the energy from PV/wind/storage battery and the energy required for charging ebike.

\section{A. Photovoltaic system}

The photovoltaic system consists of photovoltaic solar panels (PV), which produce energy in the presence of a given amount of solar irradiation. Several models are proposed in the literature [9] [18] [19]. In this work, the photovoltaic system is modeled by equation (1) [20]

$$
P_{p v}=N_{p v} \sum_{i=1}^{8760}\left(\eta_{p v} * A_{p v} * G_{i}\right)
$$

$P_{p v}: \quad$ annual production capacity of PV (Watt)

$N_{p v}: \quad$ number of PV

$\eta_{p v}: \quad$ PV efficiency (\%)

$A_{p v}: \quad$ PV surface (m2)

$G_{i}: \quad$ solar irradiation $(\mathrm{W} / \mathrm{m} 2)$

8760 : number of hours in a year

\section{B. Wind generator}

The mathematical modeling of the wind turbine is given by equation (2) [3] 
$\mathrm{P}_{w t}=\left\{\begin{array}{ccc}0 & \text { if } & v(t)<v_{\text {cutin }}, v(t)>v_{\text {cutout }} \\ N_{e o l} \sum_{t=1}^{8760}\left(\frac{v(t)^{3}-v_{\text {cutin }}^{3}}{v_{r}^{3}-v_{\text {cutin }}^{3}}\right) & \text { if } & v_{\text {cutin }}<v(t)<v_{r} \\ N_{\text {eol }} P_{r} & \text { if } & v_{r}<v(t)<v_{\text {cutout }}\end{array}\right.$

$P_{w t}: \quad$ the total annual production capacity of wind turbine (W)

$v: \quad$ the wind speed at time $\mathrm{t}$

$v_{\text {cutin }}: \quad$ cut-in speed

$v_{\text {cutout }}:$ cut-out speed

$N_{\text {eol }}: \quad$ number of wind turbine

$v_{r}: \quad$ nominal speed of wind turbine

C. Average power of the PV/Wind/storage battery and ebike

To calculate the power produced by the solar and wind turbine, as well as the average power required by the ebike, equation (3) is used.

$$
P^{m o y, i}=\frac{1}{N} \sum_{t=1}^{N} P^{i}\left(P^{i}>0\right)(t)
$$

$P^{i} \quad$ the power of each component $i$

$i \quad$ stands respectively for: solar panel, wind turbine and ebike

$N \quad$ the non-zero values of $P^{i}$

\section{Storage batteries}

The storage battery is modeled using equation (4) [18], [19]

$$
C_{b}=\frac{\sum_{t}^{8760} E_{L}(t) * A D}{V_{b} * D o D_{\max } * T_{c f} * \eta_{i n v} * \eta_{b}}
$$

$\begin{array}{ll}C_{b} & \text { storage batteries capacity } \\ E_{L} & \text { energy charging demand (ebike) } \\ A D & \text { number of autonomy days } \\ V_{b} & \text { the operating voltage } \\ D o D_{\max } & \text { maximum discharge depth } \\ T_{c f} & \text { the temperature correction factor } \\ \eta_{i n v} & \text { the inverter efficiency } \\ \eta_{b} & \text { the battery efficiency. }\end{array}$

\section{E. Charging profile modeling}

The ebike batteries considered in this work are lithium cell batteries. The model used is that of a Li-ion battery cell A123.26650. It is modeled by the second-order equivalent circuits (figure 2). To take into account the thermal behaviour inside the batteries during the charging and discharging process, the electro-thermal model in
Figure 3 is proposed. $R_{s}(t), R_{1}(t)$ and $R_{2}(t)$ are nonlinear parameters. They indicate respectively the internal resistor, the charge transfer and the diffusion process resistor. The non-linear parameters $C_{1}(t)$ and $C_{2}(t)$ indicate respectively the capacitors' capacities related to the charge transfer impedances and the diffusion process. The model parameters are validated from experimental tests in the work [10] [21]. The voltages Vocv, $V_{1}(t), V_{2}(t)$ and $V_{T}$ refer respectively to the open circuit voltage, the voltage drop during charge transfer, the voltage drop during the diffusion process and the terminal voltage of an ebike battery cell. The charging current is negative when charging and positive when discharging.

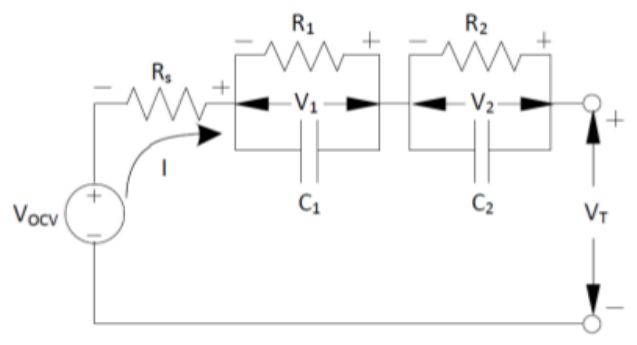

Figure 2. electrical equivalent model of an A123 Li-ion cell

The model parameters are given by equation (5)

$$
\left\{\begin{aligned}
\frac{\mathrm{dSOC}(\mathrm{t})}{\mathrm{d} t} & =-\frac{I(t)}{C_{n}} * \frac{1}{3600} \\
\frac{\mathrm{dV}_{1}(\mathrm{t})}{\mathrm{d} t} & =-\frac{\left.V_{1}(t)\right)}{R_{1}(t) * C_{1}(t)}+\frac{I(t)}{C_{1}(t)} \\
\frac{\mathrm{dV}(\mathrm{t})}{\mathrm{d} t} & =-\frac{\left.V_{2}(t)\right)}{R_{2}(t) * C_{2}(t)}+\frac{I(t)}{C_{2}(t)}
\end{aligned}\right.
$$

These parameters are time variables; they depend on ebike battery temperature and state of charge ( $s o c)$. The parameters values, as well as the experimental protocol that led to the validation of the electro-thermal model are recorded in the work [21] [22].

The cell output voltage is given by equation (6).

$$
V_{T}(t)=V \operatorname{ocv}(\operatorname{soc}(t))-V_{1}(t)-V_{2}(t)-R_{0}(t) * I(t)
$$

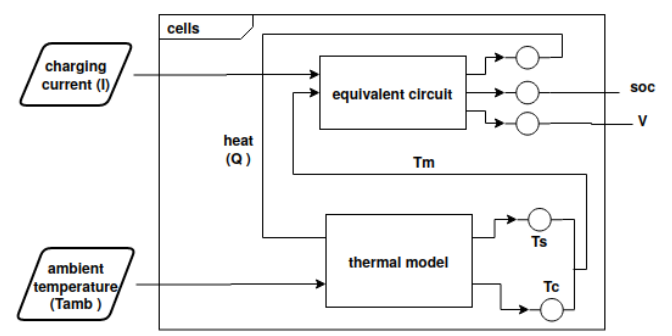

Figure 3. electrothermal coupling 
The thermal model is modeled by equation (7);

$$
\left\{\begin{array}{l}
C_{s} \frac{\mathrm{dT}_{\mathrm{s}}(\mathrm{t})}{\mathrm{d} t}=\frac{T_{a m b}-T_{s}(t)}{R_{u}}+\frac{T_{c}(t)-T_{s}(t)}{R_{c}(t)} \\
C_{c} \frac{\mathrm{dT}_{\mathrm{c}}(\mathrm{t})}{\mathrm{d} t}=\frac{T_{s}(t)-T_{c}(t)}{R_{c}}+Q(t)
\end{array}\right.
$$

$C_{s}$ : battery surface heat capacity

$C_{c}$ : battery internal heat capacity

$T_{a m b}: \quad$ ambient temperature

$T_{s}: \quad$ battery surface temperature

$T_{c}$ : battery internal temperature

$R_{u}$ : heat convection resistance

$R_{c}$ : heat conduction resistance

$Q: \quad$ battery heat dissipation

$T_{m}$ : battery average temperature

The battery heat dissipation $\mathrm{Q}(\mathrm{t})$ is modeled by equation (8)

$$
Q(t)=I(t) * T_{c}(t) \frac{\mathrm{d} \operatorname{Vocv}(\mathrm{t})}{\mathrm{d} t}-I(t)[V(t)-\operatorname{Vocv}(t)]
$$

the first term of equation(8) characterizes the entropic heat related to the entropic variation within the battery; the second term is the heat caused by potential surpluses (hysteresis, charge transfer, charge diffusion) [23]. The equation system (7) is solved to obtain the internal and surface temperature of the battery as shown in eq(9).

$$
\left\{\begin{array}{rr}
T s_{k}= & R_{c} \times T_{a m b}+R_{u} \times T c_{k-1}-\exp \left(-t_{k} \times\left(R_{c}+R_{u}\right)\right) \times \\
& \left(R_{c} \times T_{a m b}-R_{c} \times T s_{o}+R_{u} \times T c_{k-1}-R_{u} \times T s_{o}\right) \\
T c_{k}=T s_{k-1}+Q_{k-1} \times R_{c}-\exp \left(-\frac{t_{k}}{R_{c} \times C_{c}}\right) \times\left(T s_{k-1}-T c_{o}+Q_{k-1} \times\right.
\end{array}\right.
$$

$T c_{o}, T s_{o}$ represents respectively the initial internal and surface temperature of the ebike battery. The flowchart of the charging current profile is shown in Figure 4

\section{F. Energy consumption profile calculation of ebike bat- tery}

The consumption profile is obtained by summing the total energy of each battery cells. It is obtained using equation(10)

$$
E=\sum_{s=1}^{n}\left(N_{s} \times \int_{\text {to }}^{t n} U_{\text {cell }}(t) \times I(t) \times d t\right)_{s}
$$

$n$ total number of ebike batteries to be charged throughout the year

$U_{\text {cell }}$ ebike battery cell voltage

$N_{s} \quad$ the number of cells in the ebike battery

I the Mscc charging current

$s \quad$ denotes an ebike battery

to, tn start and end of charging cells
III. OBJECTIVE FUNCTION, CONSTRAINTS AND PROFIT

\section{A. Objective function}

The objective function minimizes the updated investment, replacement and maintenance costs of components (PV, Wind, storage battery, controllers and inverters).

The system's total cost $\mathrm{C}$ is given by equation (11) [24] [6] [7].

$$
C=C_{c a p}+C_{\text {repl }}+C_{\text {main }}
$$

$C_{c a p}, C_{\text {repl }}, C_{\text {main }}$ refers respectively to the capital, replacement and maintenance costs of the components. They are obtained from equations (12)(13)(14)

$$
\mathrm{C}_{\text {cap }}=N_{p v} C_{p v}+N_{e o l} C_{e o l}+N_{\text {reg }} C_{r e g}+N_{i n v} C_{i n v}+N_{b a t} C_{b a t}+C_{\text {sup }}
$$

$\mathrm{C}_{\text {repl }}=N_{p v} A_{p v} C_{p v}+N_{e o l} A_{e o l} C_{e o l}+N_{r e g} A_{r e g} C_{r e g}+N_{i n v} A_{i n v} C_{i n v}+N_{b a t} A_{b a t} C_{b a t}$

$\mathrm{C}_{\text {main }}=N_{p v} M_{p v}+N_{e o l} M_{e o l}+N_{r e g} M_{r e g}+N_{i n v} M_{i n v}+N_{b a t} M_{b a t}$

$$
\begin{aligned}
& C_{c a p} \quad \text { the acquisition cost (capital) } \\
& C_{\text {repl }} \quad \text { replacement cost } \\
& C_{\text {main }} \quad \text { maintenance cost } \\
& N_{p v}, N_{e o l}, N_{b a t, N_{r e g}}, N_{i n v} \quad \text { the number of solar panels, wind turbine, } \\
& \text { storage battery, controller and inverter } \\
& A_{p v}, A_{\text {eol }}, A_{b a t, A_{\text {reg }}}, A_{\text {inv }} \quad \text { the number of times each component is } \\
& \text { replaced over the system's lifetime } \\
& M_{p v}, M_{e o l}, M_{b a t, M_{r e g}}, M_{i n v} \text { maintenance costs for each component } \\
& C_{p v}, C_{e o l}, C_{b a t}, C_{r e g}, C_{i n v} \text { the investment costs of the components } \\
& \text { (PV/Wind/storage battery, controller, inverter) }
\end{aligned}
$$

${ }^{(9)} C_{\text {sup }}$ represents the additional investment costs integrating the infrastructure and wind turbine mast costs. It is calculated using equation (15) [25]

$$
C_{\text {sup }}=\frac{30}{100} N_{\text {eol }} C_{\text {eol }}+\frac{20}{100} N_{\text {eol }} C_{\text {eol }}
$$

To take into account the inflation rate on the market, the actualization factor is used [9]. Thus, the discounted cost of the system is given by equations $(16)(17)(18)$

$$
\begin{aligned}
C_{a, \text { cap }} & =\frac{i(i+1)^{y}}{(1+i)^{y}-1} C_{c a p} \\
C_{a, \text { rep }} & =\frac{i}{(1+i)^{y}-1} C_{r e p} \\
C_{a, \text { main }}(n) & =C_{\text {main }}(1)\left(1+i_{n f}\right)^{n}
\end{aligned}
$$

$i$ is the annual interest rate shown in equation (19)

$$
i=\frac{i^{\prime}-i_{n f}}{1+i_{n f}}
$$

$\begin{array}{ll}i^{\prime} & \text { the nominal interest rate } \\ i_{n f} & \text { the annual inflation rate } \\ y & \text { the component's lifetime } \\ C_{a, \text { main }}(n) & \text { the maintenance cost in the } n^{\text {th }} \text { year } \\ C_{a, \text { main }}(1) & \text { the maintenance cost in the } 1^{\text {st }} \text { year }\end{array}$




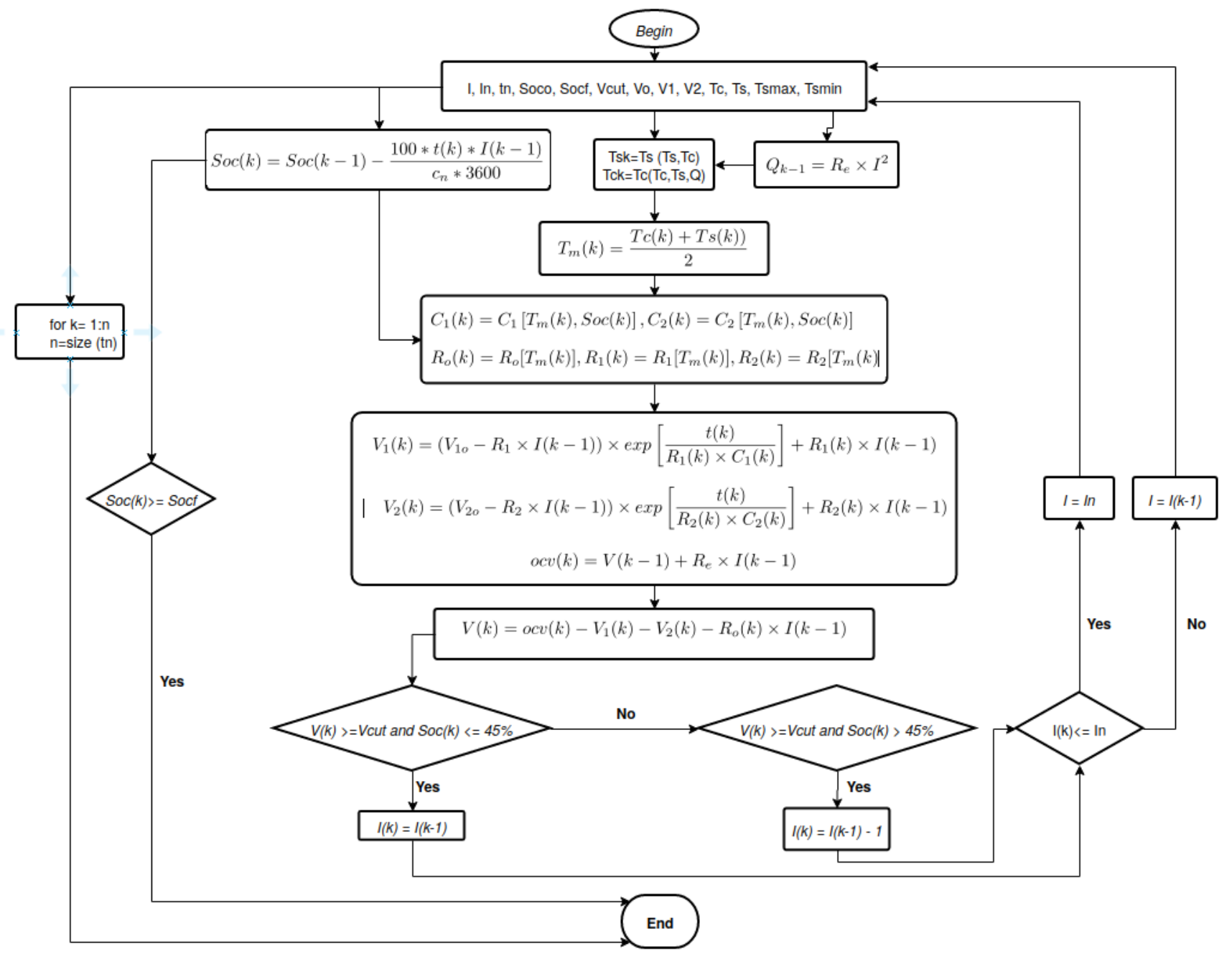

Figure 4. current profile flowchart of ebike battery cells

The objective function is then calculated using equation (20)

$$
f=\min \left[C_{a, c a p}(x)+C_{a, r e p}(x)+C_{a, \operatorname{main}}(x)\right]
$$

where, $x=\left[N_{p v}, N_{e o l}, N_{b a t}\right]$

\section{B. Constraints}

The constraints used in this work are given by equations $(21)(22)(23)(24)$

$$
\begin{gathered}
N_{p v, \text { min }} \leqslant N_{p v} \leqslant N_{p v, \text { max }} \\
N_{e o l, \text { min }} \leqslant N_{e o l} \leqslant N_{e o l, \text { max }} \\
N_{b a t, \text { min }} \leqslant N_{b a t} \leqslant N_{b a t, \text { max }} \\
P_{p v}+P_{e o l}+P_{b a t} \geqslant P_{\text {demand }}
\end{gathered}
$$

$N_{p v, \min }, N_{p v, \max }$

$N_{e o l, \min }, N_{e o l, \max }$

$N_{b a t, \min }, N_{b a t, \max }$

$C_{a, \operatorname{main}}(n)$

$P_{p v}$

$P_{\text {eol }}$

$P_{b a t}$

$P_{\text {demand }}$ the minimum and maximum number of PV

the minimum and maximum number of wind turbines the minimum and maximum number of storage battery the maintenance cost in the $n^{\text {th }}$ year the power of solar panel, power of the wind turbine, power of the storage battery ebike charging demand power

\section{C. profit and cost reduction ratio}

the profit and cost reduction ratio are shown in equation (25) and equation (26)

$$
P=C-f
$$




$$
\eta=\frac{C-f}{C} \times 100
$$

P: $\quad$ profit

$\eta:$ cost reduction ratio

\section{PARTICLE SWARM OPTIMIZATION}

The concept and PSO characteristic equations are detailed in the work [2]. The principle of PSO consists in defining an objective function, then looking for the optimal constraint values to minimize the objective function. The population in the particle swarm optimization is called a swarm, each entity of population is called a particle.

The instruction steps of the PSO are [2]:

step 1 : input the ebike charging profile, meteorological data (solar potential, wind potential) of the studied area, the economic data (cost per unit of power) of photovoltaic panel, wind turbine, the storage battery and any charge controllers.

step 2 : Initialization:

for each particle $\mathrm{N}$,

- initialize the position $x_{i}(0)$ for any $i \epsilon 1$ : $N$

- initialize the best particle position to its initial position $P_{i}(0)=x_{i}(0)$

- Calculate the fitness function of each particle and if $f\left(x_{j}(0)\right) \succeq f\left(x_{i}(0)\right)$ for all $i \neq j$, initialize the memory $g_{\text {best }}=x_{j}(0)$

step 3 : repeat until the stop criterion

- update the particle velocity according to equation (27)

$\mathrm{V}_{i}(t+1)=V_{i}(t)+c_{1}\left(p_{i}-x_{i}(t)\right) R_{1}+c_{2}\left(g-x_{i}(t)\right) R_{2}$

- update the particle position according to equation (28)

$$
x_{i}(t+1)=x_{i}(t)+v_{i}(t+1)
$$

- evaluate the particle's fitness function $f\left(x_{i}(t+1)\right)$

○ if $f\left(x_{i}(t+1)\right) \succeq f\left(p_{i}\right)$, update $p_{\text {best }, i}=x_{i}(t+1)$

$\circ \quad$ if $f\left(x_{i}(t+1)\right) \succeq f(g)$, update $g_{\text {best }}=x_{i}(t+1)$

step 4 : the best solution is represented by $g_{\text {best }}$

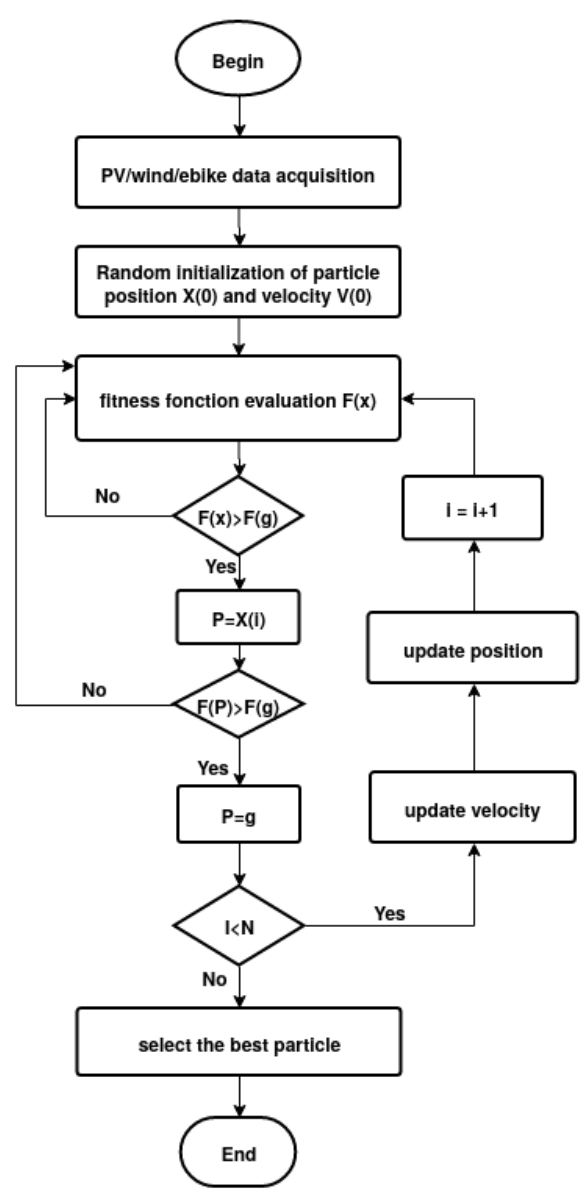

Figure 5. Optimization flowchart with the PSO

\section{FINDINGS AND ILLUSTRATIONS}

A. Case study: context of the Polytech Annecy campus

In this work, a usage scenario of twelve different ebike batteries in the campus of Polytech Annecy in France is used. This scenario is used to determine the energy consumption profile of ebike. The usage profile of the charging station is given in Figure 6; it consists of five charging spots, which can be used by ebike users between 8:00 am and 5:00 pm. The full-charge time indicated by the manufacturer is three hours. This value is used as a reference value to calculate the charging time of each ebike on the usage profile.

- charging spot 1: the ebike user plugs in "battery $1 "$ to the charging spot 1 at 08:00 am, with an initial state of charge of $30 \%$; the final state of charge $(95 \%)$ is reached when it is 10:48 am. Another user plugs in the "battery 2" at 2:00 pm, with an initial state of charge of $40 \%$; the final state of charge $(95 \%)$ is reached at 4:24 pm;

- charging spot 2: the "battery3" is plugged in to 
the charging spot 2 at 10:00 a.m., with an initial state of charge of $42 \%$; the final state of charge $(95 \%)$ is reached when it is $12: 20 \mathrm{pm}$. A few hours later, another user plugs in "battery4" to the charging spot 2 at 1:00 pm, with an initial state of charge of $20 \%$; the final state of charge $(95 \%)$ is reached at $4: 12 \mathrm{pm}$;

- charging spot 3: The user plugs in "battery $5 "$ to the charging spot 3 at 9:00 am, with an initial state of charge of 54\%; ten minutes later, "battery 6" with an initial state of charge of $35 \%$ is plugged in to the same spot by a second user; the final state of charge is obtained when it is $1: 36 \mathrm{pm}$. A third user plugged in the "battery 7" at 3:00 pm with an initial state of charge of $60 \%$, the final state of charge is obtained at $4: 36 \mathrm{pm}$.

- charging spot 4: the "battery 8" initially at 50\% is charged between 8:00 am and 10:00 am by a first user; the "battery9" initially at $38 \%$ is then charged from 10:30 to 12:59 am; finally the "battery 10" with an initial state of charge of $65 \%$ is connected from 2:00 pm to 3:24 pm.

- charging spot 5: the "battery11" with an initial state of charge of $15 \%$ is plugged in at 8:00 am, the end of charge is obtained when it is 11:24 am; thirty-six minutes later, the "battery 12 " initially at $25 \%$ is charged between 12:00 and 3:00 pm

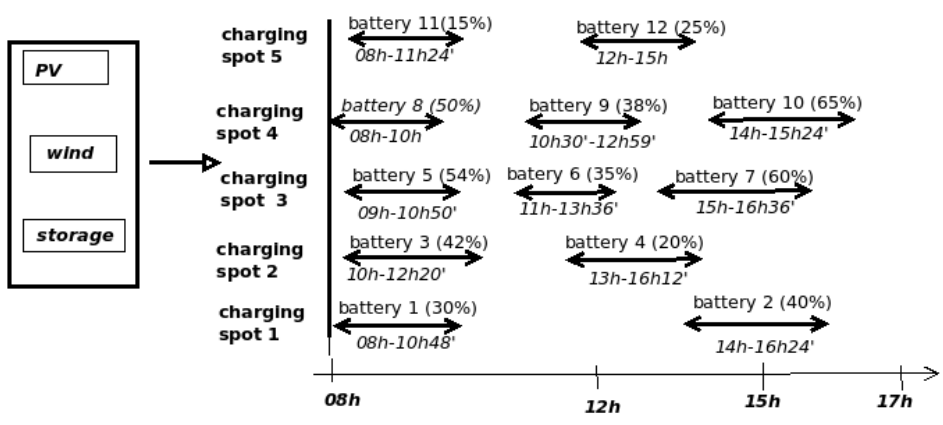

Figure 6. charging station usage

The simulation parameters used for PSO and the charging profile are listed in Tables I and II

The component costs used in this work are presented in Table (III)

\section{B. Available power from solar pannels and wind turbine}

Data used in this work for sizing the charging sation are those of year 2019 (January 1, 2019 to December
Table I. CHARGING PROFILE SIMULATION PARAMETERS

\begin{tabular}{|c|c|}
\hline cells type & $\mathrm{Li}$-ion $\mathrm{A} 123,26650$ \\
Initial surface temperature, Tso & $25^{\circ} \mathrm{C}$ \\
initial internal Temperature, Tco & $25^{\circ} \mathrm{C}$ \\
initial charging current, I & $10(\mathrm{~A})$ \\
final charging current, In & $0(\mathrm{~A})$ \\
nominal capacity, Cn & $2.5 \mathrm{Ah}$ \\
Surface charging capacity: Cs & $62.8 J . K^{-1}$ \\
Internal heat capacity Cc & $4.5 J . K^{-1}$ \\
heat conduction resistance Rc & $62.7 K . W^{-1}$ \\
convection resistance Ru & $3.19 K . W^{-1}$ \\
ambient temperature: Tamb & $25^{\circ} \mathrm{C}$ \\
cut-off voltage & $3.6 \mathrm{~V}$ \\
minimal voltage & $3 \mathrm{~V}$ \\
final state of charge, SOC & $95 \%$ \\
number of cells & $12 \mathrm{cells}$ \\
\hline
\end{tabular}

Table II. INPUT PARAMETERS FOR PSO

\begin{tabular}{|c|c|c|}
\hline parameters & significations & values \\
\hline$N_{\min }$ & minimal number of PV, wind, storage battery & 1 \\
$N_{\max }$ & maximum number of PV, Wind, storage battery & 30 \\
Maxit & maximum iteration & 30 \\
$\mathrm{p}$ & number of particle & 500 \\
$c_{1}$ & local acceleration coefficient & 2.05 \\
$c_{2}$ & global acceleration coefficient & 2.05 \\
$w_{\max }$ & maximum coefficient of inertia & 0.9 \\
$w_{\min }$ & minimum coefficient of inertia & 0.4 \\
$i$ & annual interest rate & 0.6 \\
$i_{n f}$ & inflation factor & 0.04 \\
$\eta_{\text {ond }}$ & inverter efficiency & 0.95 \\
$v_{r}$ & nominal wind speed & $12 \mathrm{~m} / \mathrm{s}$ \\
$v_{\text {cutin }}$ & wind cut-in speed & $2 \mathrm{~m} / \mathrm{s}$ \\
$v_{\text {cutout }}$ & wind cut-out speed & $45 \mathrm{~m} / \mathrm{s}$ \\
$A D$ & number of autonomy days & 1 \\
$V_{B}$ & storage battery voltage & $12 \mathrm{volt}$ \\
$T_{\text {cf }}$ & temperature correction factor & 0.8 \\
\hline
\end{tabular}

Table III. INPUT PARAMETERS FOR COMPONENTS

\begin{tabular}{|cccccc|}
\hline components & power & $\begin{array}{c}\text { lifetime } \\
\text { (year) }\end{array}$ & $\begin{array}{c}\text { initial cost } \\
\text { (euro) }\end{array}$ & $\begin{array}{c}\text { A } \\
\text { (without units) }\end{array}$ & $\begin{array}{c}\text { maintenance costs } \\
\text { (euro) }\end{array}$ \\
\hline PV & $270(\mathrm{Wc})$ & 25 & 191 & 0 & 1.91 \\
wind & $3.2(\mathrm{~kW})$ & 25 & 309 & 0 & 3.09 \\
regulator & & 25 & 397 & 1 & 3.97 \\
battery & $1.56 \mathrm{kWh}$ & 10 & 345 & 2 & 3.45 \\
inverter & $3 \mathrm{kVA}$ & 15 & 1272 & 1 & 12.72 \\
\hline
\end{tabular}

31, 2019). In figure 7, one month profile is presented, showing PV/wind power production from the december 01, 2019 to dec 31, 2019. They are obtained from the soda site [26]

\section{Current and charging profile}

The charging current profile of the ebike battery cells is shown in Figure8. It corresponds to ebike battery charging currents presented on the charging station's usage profile. Results show a difference in battery charging time depending on the initial state of charge. The lower the initial state of charge, the longer the charging time.

To obtain the overall battery charging profile, the total number of cells in each battery is calculated using equation (10). The consumption profile is shown in Figure 9.

It shows a peak consumption of $595.85 \mathrm{~W}$ at $08: 00 \mathrm{am}$ compared to $34.81 \mathrm{~W}$ at $3.00 \mathrm{pm}$. This change in consumption is justified by: 

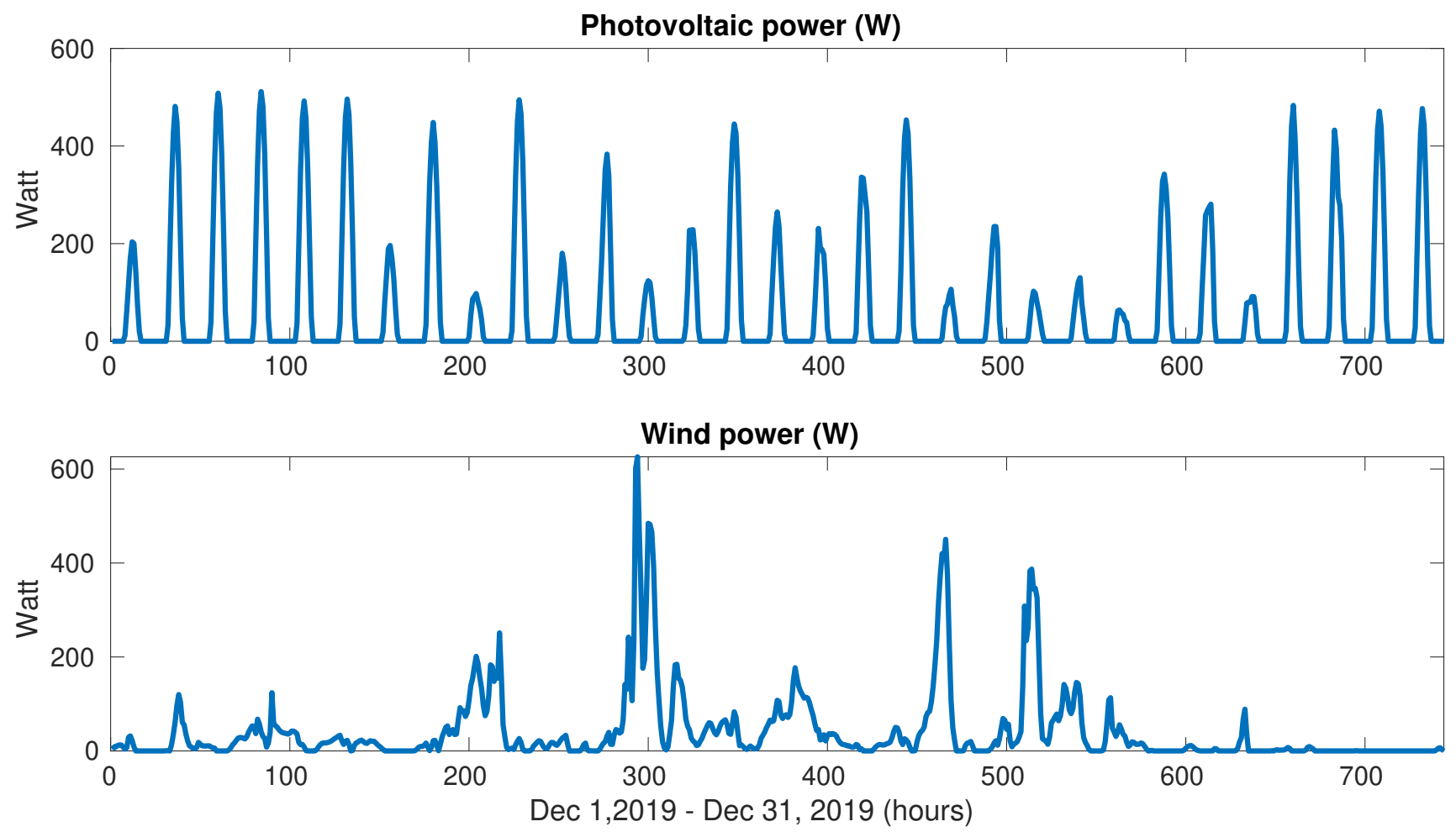

Figure 7. Solar and Wind power from December 2019

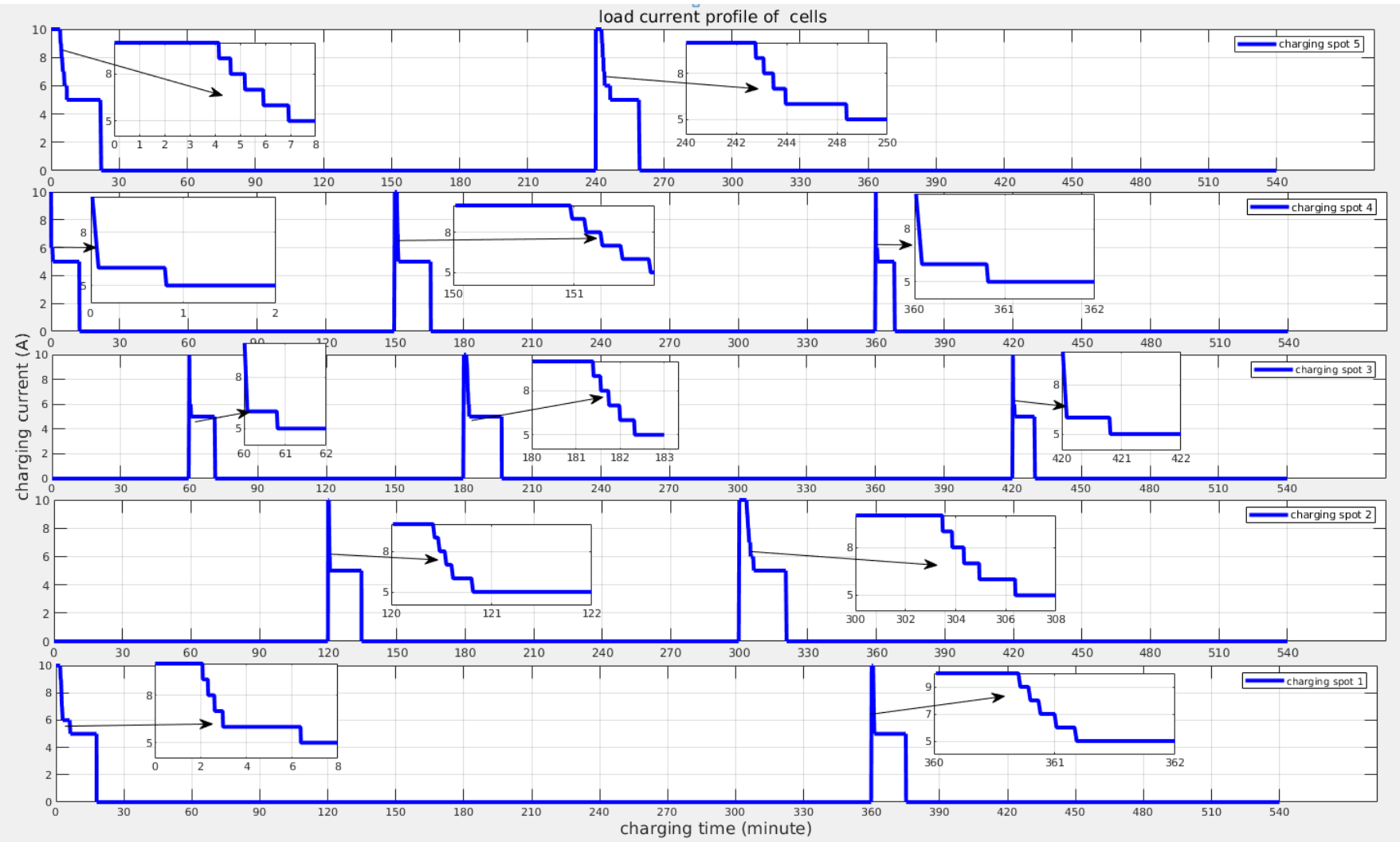

Figure 8 . charging current profile of ebike battery cells 


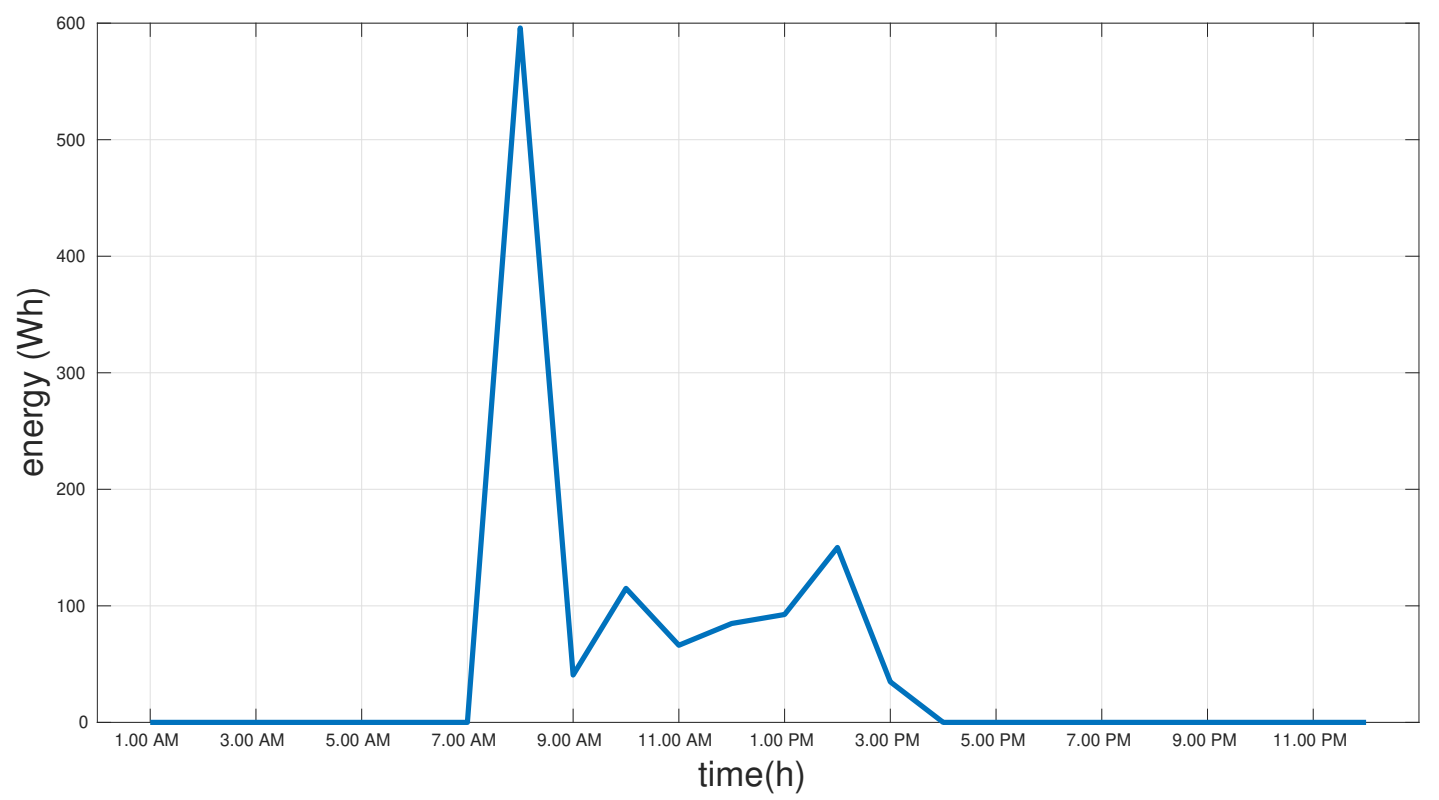

Figure 9. daily consumption profile of ebike batteries at the charging station

- the simultaneous connection of ebike 1 (battery 1), ebike 8 (battery 8 ) and ebike11 (battery 11) at $08.00 \mathrm{am}$, with an initial state of charge of $30 \%$, $50 \%$ and $15 \%$ respectively;

- $\quad$ the state of charge of ebike 2 (battery 2), ebike 7 (battery 7), ebike 10 (battery 10). Indeed, when it is $3.00 \mathrm{pm}$, these batteries are close to the maximum state of charge of $95 \%$. This is why a low power consumption of the ebike is observed at $3: 00 \mathrm{pm}$.

\section{Sizing results}

Ebike charging station sizing result is shown in Table IV. These results show that, one photovoltaic solar panel,

Table IV. SIZING RESULT

\begin{tabular}{|c|c|c|c|}
\hline Items & solar panel & wind turbine & storage battery \\
\hline number & 1 & 1 & 1 \\
\hline
\end{tabular}

one wind turbine and one storage battery are sufficient to cover the annual charging requirements of the ebike. Indeed, the average power consumed by ebike is 147.5 $\mathrm{W}$. The average power output of PV and wind sources are respectively 419.82 and $69.76 \mathrm{~W}$, which fully meet the ebike charging requirements. The unit value of the storage battery can be justified by the low power production of the solar panel and wind turbine during the unused period of the charging station. Indeed, there is no energy output from solar panel after $5 \mathrm{pm}$, therefore only the wind turbine power production is stored in the storage battery after this time. In addition, a low power production of the wind turbine (69.75 Watt) is observed on site. Therefore, only one battery is needed to store the produced energy from the permanence hours of the charging station (when there is no charging demand).

The average output power of solar panel, wind turbine and charging demand are presented in tableV.

Table V. AVERAGE POWER PRODUCTION AND CHARGING CAPACITY

\begin{tabular}{|c|c|}
\hline Items & Values (W) \\
\hline PV & 419.42 \\
\hline wind & 69.76 \\
\hline ebike & 147.50 \\
\hline
\end{tabular}

\section{E. PSO convergence curve}

The convergence curve on cost optimization is shown in figure 10. It shows a total system cost convergence from 4681.9 euros to an optimal value of 2055.6 euros. This result corresponds to a profit of 2626.9 euro, representing a $56.11 \%$ cost reduction compared to the cost without optimization. Optimal cost is obtained after 4 iterations. This characterizes the efficiency of the particle swarm optimization used for sizing. Sizing costs with and without optimization are shown in table VI 


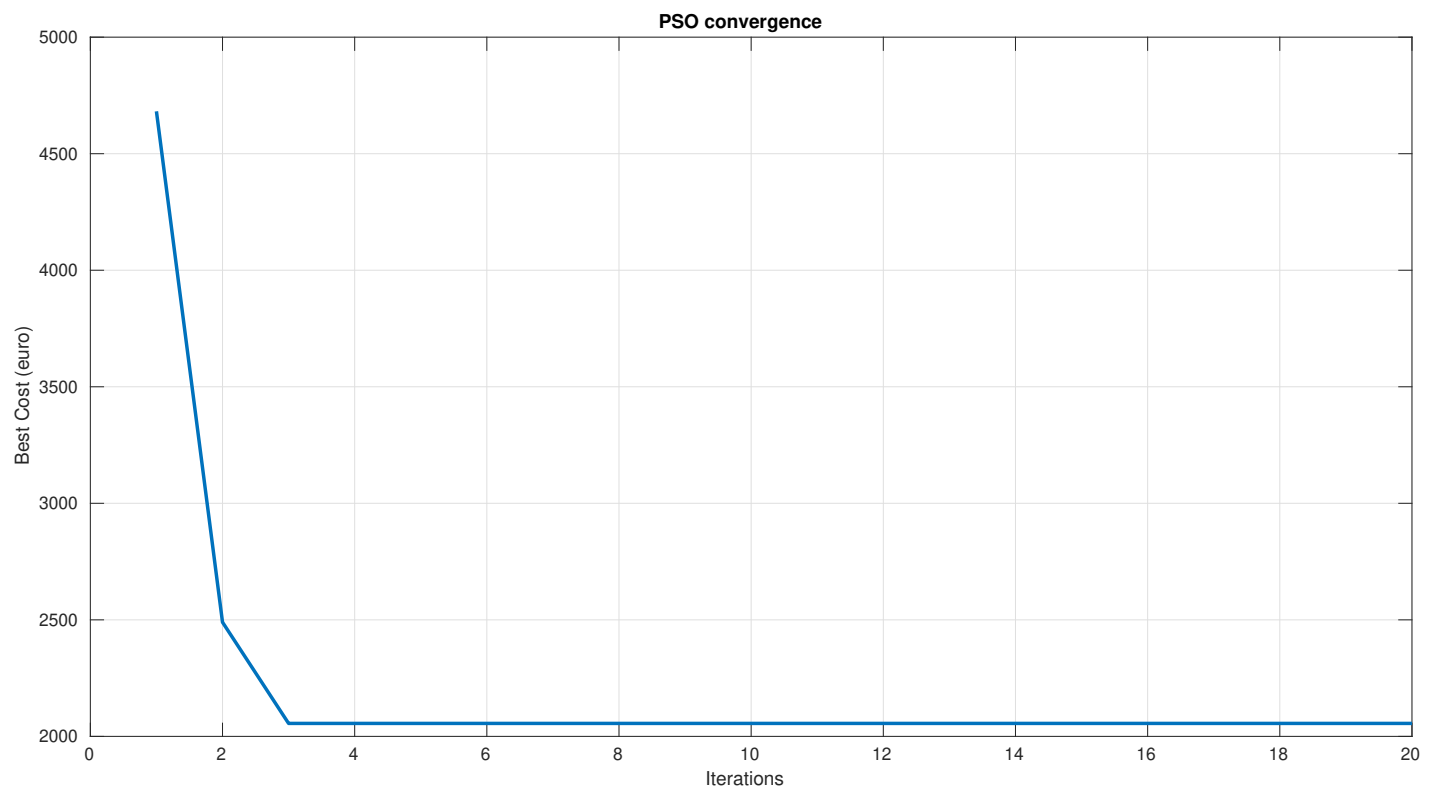

Figure 10. cost convergence curve

Table VI. COSTS OPTIMIZATION PROFIT

\begin{tabular}{|c|c|c|c|}
\hline $\begin{array}{c}\text { cost without } \\
\text { optimization }\end{array}$ & $\begin{array}{c}\text { optimized cost } \\
\text { with PSO }\end{array}$ & profit & cost reduction \\
\hline 4681.9 euros & 2055.6 euros & 2626.9 euros & $56.11 \%$ \\
\hline
\end{tabular}

\section{CONCLUSiON}

The Mscc protocol applied to the second order equivalent circuit allowed to design the charging profile of the ebike batteries. The investment, replacement and maintenance costs of the components allowed to define the objective function, which is minimized using PSO. The results obtained allowed to understand the PSO's benefit in the sizing of the ebike charging stations. This work was limited to a PV/wind/battery hybrid system. In future, we intend to integrate the national grid in the energy sources, then to study advantages of using ebike batteries as a buffer battery in the sizing optimization of a charging station.

\section{ACKNOWLEDGMENT}

Authors would like to thank the CEA-MITIC and Eurasmus+ MIC funding programs, which enabled us to carry out this work.

\section{REFERENCES}

[1] A. Muetze and Y. Tan, "Performance evaluation of electric bicycles," in Fourtieth IAS Annual Meeting. Conference Record of the 2005 Industry Applications Conference, 2005., vol. 4, (Hong Kong, China), pp. 2865-2872, IEEE, 2005.
[2] D. Sadeghi, A. Hesami Naghshbandy, and S. Bahramara, "Optimal sizing of hybrid renewable energy systems in presence of electric vehicles using multi-objective particle swarm optimization,” Energy, vol. 209, p. 118471, Oct. 2020.

[3] H. Mehrjerdi, "Modeling, integration, and optimal selection of the turbine technology in the hybrid wind-photovoltaic renewable energy system design," Energy Conversion and Management, vol. 205, p. 112350, Feb. 2020.

[4] M. Gharibi and A. Askarzadeh, "Size and power exchange optimization of a grid-connected diesel generator-photovoltaicfuel cell hybrid energy system considering reliability, cost and renewability," International Journal of Hydrogen Energy, vol. 44, pp. 25428-25441, Oct. 2019.

[5] T. Salameh, C. Ghenai, A. Merabet, and M. Alkasrawi, "Techno-economical optimization of an integrated stand-alone hybrid solar PV tracking and diesel generator power system in Khorfakkan, United Arab Emirates," Energy, vol. 190, p. 116475, Jan. 2020.

[6] V. Khare, S. Nema, and P. Baredar, "Optimization of hydrogen based hybrid renewable energy system using HOMER, BBBC and GAMBIT," International Journal of Hydrogen Energy, vol. 41, pp. 16743-16751, Oct. 2016.

[7] O. H. Mohammed, Y. Amirat, and M. Benbouzid, "Particle Swarm Optimization Of a Hybrid Wind/Tidal/PV/Battery Energy System. Application To a Remote Area In Bretagne, France," Energy Procedia, vol. 162, pp. 87-96, Apr. 2019.

[8] M. Samy, M. I. Mosaad, and S. Barakat, "Optimal economic study of hybrid PV-wind-fuel cell system integrated to unreliable electric utility using hybrid search optimization technique," International Journal of Hydrogen Energy, Sept. 2020.

[9] S. Barakat, H. Ibrahim, and A. A. Elbaset, "Multi-objective optimization of grid-connected PV-wind hybrid system considering reliability, cost, and environmental aspects," Sustainable Cities and Society, vol. 60, p. 102178, Sept. 2020. 
[10] K. Liu, X. Hu, Z. Yang, Y. Xie, and S. Feng, "Lithiumion battery charging management considering economic costs of electrical energy loss and battery degradation," Energy Conversion and Management, vol. 195, pp. 167-179, Sept. 2019.

[11] P. Keil and A. Jossen, "Charging protocols for lithium-ion batteries and their impact on cycle life-An experimental study with different 18650 high-power cells," Journal of Energy Storage, vol. 6, pp. 125-141, May 2016.

[12] Y. Li, K. Li, Y. Xie, J. Liu, C. Fu, and B. Liu, "Optimized charging of lithium-ion battery for electric vehicles: Adaptive multistage constant current-constant voltage charging strategy," Renewable Energy, vol. 146, pp. 2688-2699, Feb. 2020.

[13] K. Anoune, M. Bouya, A. Astito, and A. B. Abdellah, "Sizing methods and optimization techniques for PV-wind based hybrid renewable energy system: A review," Renewable and Sustainable Energy Reviews, vol. 93, pp. 652-673, Oct. 2018.

[14] M. Amjad, A. Ahmad, M. H. Rehmani, and T. Umer, "A review of EVs charging: From the perspective of energy optimization, optimization approaches, and charging techniques," Transportation Research Part D: Transport and Environment, vol. 62, pp. 386-417, July 2018.

[15] A. Mostafaeipour, M. Jahangiri, A. Haghani, S. J. H. Dehshiri, S. S. H. Dehshiri, A. Issakhov, A. Sedaghat, H. Saghaei, E. T. Akinlabi, S. M. Sichilalu, S. Chowdhury, and K. Techato, "Statistical evaluation of using the new generation of wind turbines in South Africa," Energy Reports, vol. 6, pp. 28162827, Nov. 2020.

[16] S.-Y. Chen, C.-H. Wu, Y.-H. Hung, and C.-T. Chung, "Optimal strategies of energy management integrated with transmission control for a hybrid electric vehicle using dynamic particle swarm optimization," Energy, vol. 160, pp. 154-170, Oct. 2018.

[17] Y. Wu, A. Ravey, D. Chrenko, and A. Miraoui, "Demand side energy management of EV charging stations by approximate dynamic programming," Energy Conversion and Management, vol. 196, pp. 878-890, Sept. 2019.

[18] K. Anoune, M. Ghazi, M. Bouya, A. Laknizi, M. Ghazouani, A. B. Abdellah, and A. Astito, "Optimization and technoeconomic analysis of photovoltaic-wind-battery based hybrid system," Journal of Energy Storage, vol. 32, p. 101878, Dec. 2020.

[19] E. Eriksson and E. Gray, "Optimization of renewable hybrid energy systems - A multi-objective approach," Renewable Energy, vol. 133, pp. 971-999, Apr. 2019.

[20] O. Mohammed, Y. Amirat, and M. Benbouzid, "Economical Evaluation and Optimal Energy Management of a StandAlone Hybrid Energy System Handling in Genetic Algorithm Strategies," Electronics, vol. 7, p. 233, Oct. 2018.

[21] H. E. Perez, J. B. Siegel, X. Lin, A. G. Stefanopoulou, Y. Ding, and M. P. Castanier, "Parameterization and Validation of an Integrated Electro-Thermal Cylindrical LFP Battery Model," in Volume 3: Renewable Energy Systems; Robotics; Robust Control; Single Track Vehicle Dynamics and Control; Stochastic Models, Control and Algorithms in Robotics; Structure Dynamics and Smart Structures;, (Fort Lauderdale, Florida, USA), pp. 41-50, ASME, Oct. 2012.

[22] X. Lin, H. E. Perez, S. Mohan, J. B. Siegel, A. G. Stefanopoulou, Y. Ding, and M. P. Castanier, "A lumped-parameter electro-thermal model for cylindrical batteries," Journal of Power Sources, vol. 257, pp. 1-11, July 2014.

[23] C. Zhang, K. Li, J. Deng, and S. Song, "Improved Realtime State-of-Charge Estimation of LiFePO \$_\{ \boldsymbol
4) \$ Battery Based on a Novel Thermoelectric Model," IEEE Transactions on Industrial Electronics, vol. 64, pp. 654-663, Jan. 2017.

[24] X. Han, Y. Liang, Y. Ai, and J. Li, "Economic evaluation of a PV combined energy storage charging station based on cost estimation of second-use batteries," Energy, vol. 165, pp. 326339, Dec. 2018.

[25] B. O. Bilal, "Mise en œuvre de nouvelles approches d'optimisation multi-objectif de systèmes hybrides éoliensolaire-batterie-groupe électrogène," p. 154.

[26] "MERRA - www.soda-pro.com." 